\section{Marine phosphorus is selectively remineralized}

Phosphorus is a vital nutrient of the world's oceans ${ }^{1,2}$, where in vast regions it is associated with dissolved organic matter (DOM) in surface waters ${ }^{3,4}$. We have characterized the major compound classes of high-molecularweight marine dissolved organic phosphorus, phosphorus esters and phosphonates, by using tangential-flow ultrafiltration and phosphorus-31 nuclear magnetic resonance $\left({ }^{31} \mathrm{P} \mathrm{NMR}\right)$. We find that the composition and abundance of organic phosphorus in DOM differ significantly from the values in fresh organic matter, indicating that dissolved organic phosphorus (DOP) is preferentially remineralized from DOM.

It has become feasible, with the advent of tangential-flow ultrafiltration, to concentrate and isolate sufficient dissolved and particulate organic matter from natural waters for NMR spectroscopic analysis ${ }^{5,6}$. Tangential-flow ultrafiltration of sea water reproducibly isolates a greater fraction of DOM than other methods, so ultrafiltered isolates represent the largest fractions of marine DOM ever characterized ${ }^{5-7}$.

In this study, $19-38 \%$ of total DOM was

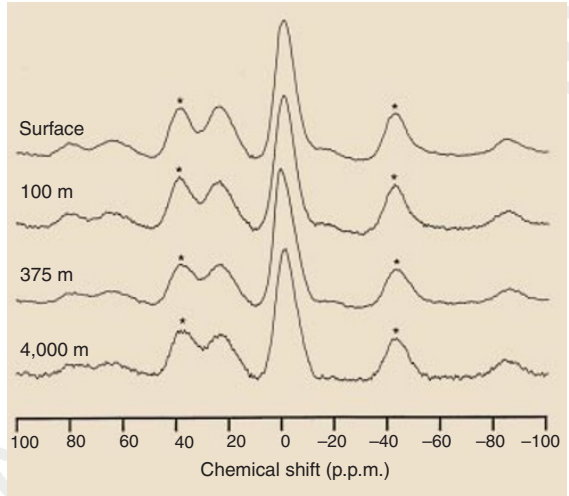

Figure 1 Phosphorus-31 cross-polarized magicangle spinning NMR spectra of organic matter in sea water. Dried high-molecular-weight DOM isolated from $\sim 1,000$ litres of sea water from the surface $100 \mathrm{~m}$ (chlorophyll maximum), $375 \mathrm{~m}$ (oxygen minimum) and $4,000 \mathrm{~m}$ in the Pacific Ocean $\left(12^{\circ} \mathrm{S}\right.$ $\left.134^{\circ} \mathrm{W}\right)^{6}$. Spectra were collected on a Chemagnetics CMX300 spectrometer at a frequency of $121.3 \mathrm{mHz}$ and a spin rate of $5 \mathrm{kHz}$. Chemical shifts are referenced to phosphoric acid. Spectra were acquired using a pulse width of $4.4 \mu \mathrm{s}$ and a pulse delay of $500 \mathrm{~ms}$. Contact time was $1 \mathrm{~ms}$. Data for surface and 100-m samples were collected over 20,000 transients, and data for 375- and 4,000-m samples were collected over 100,000 transients. Line-broadening of $50 \mathrm{~Hz}$ was applied to all samples. Asterisks denote spinning sidebands. NMR experiments with organic $P$ standard compounds were performed to ensure that changes in peak area are linearly related to changes in abundance of the $\mathrm{P}$ compounds.

\begin{tabular}{|c|c|c|c|c|}
\hline Sample & DOC & DON & DOP & $\mathrm{C} / \mathrm{N} / \mathrm{P}$ \\
\hline Surface & 22.2 & 1.33 & 0.090 & $247 / 15 / 1$ \\
\hline $100 \mathrm{~m}$ & 22.2 & 1.42 & 0.083 & $267 / 17 / 1$ \\
\hline $375 \mathrm{~m}$ & 10.6 & 0.63 & 0.033 & $321 / 19 / 1$ \\
\hline $4,000 \mathrm{~m}$ & 8.08 & 0.45 & 0.015 & $539 / 30 / 1$ \\
\hline
\end{tabular}

Concentrations of ultrafiltered dissolved organic carbon (DOC), nitrogen (DON) and phosphorus (DOP) are expressed as micromolar; C/N/P values are the calculated atom ratios.

recovered by ultrafiltration ${ }^{6}$. All the ultrafiltered DOM isolates characterized here are in the high-molecular-weight or colloidal fraction (1-100-nm size range $)^{6}$, which is a significant source of carbon and energy for marine bacteria ${ }^{8}$.

The ${ }^{31} \mathrm{P}$ NMR spectrum of surface-water DOM indicates that DOP is dominated by two major classes of compound, phosphorus esters and phosphonates (Fig. 1). The most prominent feature of all spectra is the large peak centred at a chemical shift of 0 p.p.m., attributed to phosphorus esters. In marine plankton, phosphorus esters are present as monoester and diester phosphates in macromolecules such as nucleic acids and membrane phospholipids ${ }^{9}$. The smaller peak at 25 p.p.m. indicates the presence of phosphonates, a group of compounds containing a C-P bond. Phosphonates are often associated with phosphoproteins ${ }^{10}$ and membrane phosphonolipids ${ }^{9}$. Phosphonolipids in outer-membrane structures may protect cells from enzymatic degradation or provide extra rigidity ${ }^{11,12}$.

About 3\% of total phosphorus in a natural assemblage of plankton was attributed to phosphonates ${ }^{13}$. Although phosphonates comprise only a few per cent of phosphorus in plankton, integration of NMR peak areas reveals a surprisingly high abundance of phosphonates in high-molecular-weight DOP (about 25\%). The relatively high proportion of phosphonates in surface DOP indicates preferential use of phosphorus esters relative to phosphonates during organic matter decomposition.

In sea water, some dissolved phosphorus esters are a rapidly used source of phosphorus whereas phosphonates are considered to be chemically stable compounds, more resistant to hydrolysis and bacterial degradation ${ }^{9}$. Given the higher proportion of phosphonates in surface DOP relative to marine plankton, regeneration must initially be a selective process, with reactive phosphorus esters as a preferred substrate for microorganisms.

Although the absolute concentration of high-molecular-weight DOP decreases from $90 \mathrm{nM}$ in surface waters to $15 \mathrm{nM}$ in deep waters (Table 1), ${ }^{31} \mathrm{P}$ NMR spectra of DOP show phosphorus esters and phosphonates in unchanging proportions throughout the water column (Fig. 1), indicating that phosphorus esters and phosphonates are used at equivalent rates in deeper waters. Apparent differences in the reactivity of phosphorus esters in surface compared with deeper waters may result from phosphorus esters occurring in a variety of biochemical classes of differing reactivities. Reactive phosphorus esters are used rapidly in surface waters, resulting in enrichment of deep waters in less reactive DOP compounds. The persistence of phosphorus esters and phosphonates from surface to deep waters suggests that less reactive fractions of DOP consist of common biochemical structures that are probably produced in surface waters.

The regeneration of nutrients in sea water is often compared to the Redfield ratio $^{1}$, which approximates the average composition of marine planktonic organisms (ratio of carbon/nitrogen/phosphorus $(\mathrm{C} / \mathrm{N} / \mathrm{P})$ atoms $=106 / 16 / 1)$. Although it is largely unknown whether DOM is produced in Redfield stoichiometry, our data show that DOM is depleted in phosphorus throughout the entire water column relative to Redfield values (Table 1). The dramatic increase in $\mathrm{C} / \mathrm{P}$ and $\mathrm{N} / \mathrm{P}$ ratios with depth indicates that phosphorus is preferentially regenerated from DOM, which implies that DOP must ultimately cycle more efficiently than either DOC or DON.

Selective removal of phosphorus from DOM presumably reflects the nutrient demands of marine microorganisms, suggesting that phosphorus is a limiting nutrient in surface waters of oligotrophic regions. Lauren Lisa Clark, Ellery D. Ingall,

Ronald Benner

University of Texas, Marine Science Institute,

Port Aransas, Texas 78373, USA

email: ingall@utmsi.utexas.edu

1. Redfield, A. C. Am. Sci. 46, 205-222 (1958).

2. Broecker, W. S. \& Peng, T. S. Tracers in the Sea (Eldigio, Palisades, NY, 1982).

3. Smith, S. V., Kimmerer, J. \& Walsh, T. W. Limnol. Oceanogr. 31, 161-167 (1986)

4. Karl, D. M. \& Yanagi, K. Limnol. Oceanogr. 42, 1398-1405 (1997).

5. Benner, R., Pakulski, J. D., McCarthy, M., Hedges, J. I. \& Hatcher, P. G. Science 255, 1561-1564 (1992).

6. Benner, R., Biddanda, B., Black, B. \& McCarthy, M. Mar. Chem. 57, 243-263 (1997).

7. McCarthy, M. D., Hedges, J. I. \& Benner, R. Chem. Geol. 107, 503-507 (1993)

8. Amon, R. M. W. \& Benner, R. Nature 369, 549-552 (1994).

9. Hori, T., Horiguchi, M. \& Hayashi, A. Biochemistry of Natural C-P Compounds 1-200 (Maruzen, Shiga, 1984)

10. Quin, L. D. in Topics in Phosphorus Chemistry (eds Grayson, M. \& Griffith, E. J.) 23-48 (Wiley, New York, 1967).

11. Kennedy, K. E. \& Thompson, G. A. Jr Science 168, 989-991 (1970).

12. Rosenberg, H. in Form and Function of Phospholipids (eds Ansell, G. B., Hawthorne, J. N. \& Dawson, R. M. C.) 333-344 (Elsevier, New York, 1973).

13. Kittredge, J. S., Horiguchi, M. \& Williams, P. M. Comp. Biochem. Physiol. 29, 859-863 (1969). 